\title{
Bowhead Whales Along the Chukotka Coast in Autumn
}

\author{
SUE E. MOORE, ${ }^{1}$ JOHN C. GEORGE, ${ }^{2}$ KENNETH O. COYLE ${ }^{3}$ and THOMAS J. WEINGARTNER ${ }^{3}$
}

(Received 21 September 1994; accepted in revised form 23 January 1995)

\begin{abstract}
Bowhead whales (Balaena mysticetus) were seen in autumn 1992 and 1993 only along the northern coast of Chukotka, Russia, although an extensive area of the Chukchi Sea was searched during ship cruises. Single-day counts of 76 and 50 bowheads were made on 1 October 1992 and 3 October 1993, respectively, with only a few whales seen on other days. Whales seen between Cape Schmidt and Cape Vankarem on 1 October 1992 appeared to be feeding, but there was no means to detect or sample subsurface forage that year. On 3 October 1993, bowheads appeared to be feeding in an area where a $5 \mathrm{~m} \times 8 \mathrm{~km}$ patch of zooplankton was identified, via acoustics, at $25-30 \mathrm{~m}$ in water $35 \mathrm{~m}$ deep. A vertical-tow sample near the patch indicated the euphausiid Thysanoessa rachii, a common bowhead prey species, was abundant in the water column. The location of the zooplankton patch corresponded with a sharp salinity (proxy density) gradient. In addition, whale distribution coincided with a surface thermal boundary, identified by satellite-borne Advanced Very High Resolution Radiometer (AVHRR) imagery. The confinement of bowhead sightings to the northern coast of Chukotka in 1992-93 corresponds to reports from autumn surveys in 1979, 1980 and 1990, while the association of whales with physical oceanographic fronts is similar to findings from a study of bowhead feeding areas in the southern Beaufort Sea. These observations suggest that the Chukotka coast may be an important feeding or staging area for the Bering Sea stock and that oceanographic patterns influencing whale occurrence may be identifiable from standard oceanographic measurements.
\end{abstract}

Key words: bowhead whale, Balaena mysticetus, migration, Chukchi Sea, Bering Sea, Chukotka, Thysanoessa rachii, satellite imagery, AVHRR

RÉSUMÉ. Durant l'automne de 1992 et celui de 1993, on n'a pu observer de baleines boréales (Balaena mysticetus) que le long de la côte nord de Chukotka (Russie), bien que des recherches aient eu lieu dans une zone étendue de la mer des Tchouktches lors de croisières en bateau. Des comptages de 76 et 50 baleines boréales ont été obtenus respectivement le $1^{\text {er }}$ octobre 1992 et le 3 octobre 1993, alors qu'on n'en a observé que quelques-unes les autres jours. Les baleines observées entre Cape Schmidt et Cape Vankarem le $1^{\text {er }}$ octobre 1992 semblaient être en train de s'alimenter, mais on ne disposait pas de moyens pour détecter le genre de nourriture sous la surface, ni pour en prélever un échantillon cette année-là. Le 3 octobre 1993, les baleines semblaient s'alimenter là où une plaque de zooplancton de $5 \mathrm{~m} \mathrm{x} 8 \mathrm{~km}$ avait été identifiée par méthode acoustique entre 25 et $30 \mathrm{~m}$ de profondeur, dans une zone de $35 \mathrm{~m}$ de fond. Un échantillon prélevé par hâlage vertical près de la plaque a indiqué que l'euphausiacé Thysanoessa rachii, une proie courante de la baleine boréale, était abondant dans la colonne d'eau. L'emplacement de la plaque de zooplancton correspondait à un fort gradient de salinité (approximation par la densité). De plus, la distribution des baleines coïncidait avec une limite thermique de surface identifiée au moyen de l'imagerie par radiomètre perfectionné à très haute résolution, transporté par satellite. Le confinement des observations de baleines à la côte nord de Chukotka en 1992-93 correspond aux rapports des relevés d'automne de 1979, 1980 et 1990, tandis que l'association des baleines à des fronts physiques océanographiques cadre avec les résultats d'une étude des zones d'alimentation de la baleine boréale dans le sud de la mer de Beaufort. Ces observations suggèrent que la côte de Chukotka pourrait être une importante zone d'alimentation ou de rassemblement pour la population de la mer de Béring, et que les caractéristiques océanographiques qui influencent la présence des baleines pourraient être identifiables à partir des mesures océanographiques courantes.

Mots clés: baleine boréale, Balaena mysticetus, migration, mer des Tchouktches, mer de Béring, Chukotka, Thysanoessa rachii, imagerie par satellite, radiomètre perfectionné à très haute résolution

Traduit pour la revue Arctic par Nésida Loyer.

\section{INTRODUCTION}

The Bering Sea population of bowhead whales (Balaena mysticetus) migrates ca. $2500 \mathrm{~km}$ each spring from wintering areas in the Bering Sea to summering areas in the Beaufort
Sea. Whales swim north and east from the Bering Sea in April and May and arrive from June to July in the eastern Beaufort Sea, where they spend the summer feeding (Moore and Reeves, 1993). Since 1976, a census has been conducted during the spring migration from shorefast ice perches near

\footnotetext{
${ }^{1}$ SAIC, Maritime Services Division, 3990 Old Town Avenue, Suite 105A, San Diego, California 92110, U.S.A.

${ }^{2}$ North Slope Borough, Department of Wildlife Management, P.O. Box 69, Barrow, Alaska 99723, U.S.A.

${ }^{3}$ University of Alaska/Fairbanks, Institute of Marine Science, Fairbanks, Alaska 99775, U.S.A.

(C) The Arctic Institute of North America
} 
Barrow, Alaska (Zeh et al., 1993). Visual counts, augmented since 1984 by passive acoustic detection, have resulted in an estimate of 8000 whales $(95 \%$ C.I. $=6900-9200)$ in this population (Zeh et al.,1995).

Some biologists conclude that almost the entire Bering Sea bowhead population migrates to the Beaufort Sea each spring and that few, if any, whales summer in the Chukchi Sea (Dahlheim et al., 1980; Miller et al., 1986). Conversely, Russian scientists maintain that some bowheads migrate through the Bering Strait in late spring, swim northwest along the Chukotka coast and summer in the Chukchi Sea (Bogoslovskaya et al., 1982; Bessonov et al., 1990). There has been little new evidence to support or refute either view (Burns, 1993). A collation of incidental sighting records over the years from 1975 to 1991 suggests that bowheads may regularly occur along the northwestern Alaskan coast in late summer, but it is unclear whether these are 'early autumn' migrants or whales that have summered nearby (Moore, 1992).

Bowheads swim west and south from the Beaufort Sea from late August through October and arrive in the Bering Sea by November (Moore and Reeves, 1993). Daily whale sighting rates derived from aerial surveys over the northeastern Chukchi Sea during autumn from 1982 to 1991 demonstrated an annual peak from early to mid-October (Moore and Clarke, 1992). During these surveys, bowheads were never detected in the central Chukchi Sea (i.e., south of $70^{\circ} \mathrm{N}$ or west of $166^{\circ} \mathrm{W}$ ), so the autumn migration route back to the Bering Sea remains largely unknown. In autumn 1992 and 1993, oceanographic cruises aboard the R/V Alpha Helix provided a means to opportunistically survey for bowhead whales in the Chukchi Sea. The results are summarized below.

\section{METHODS}

During the cruises, a marine mammal/seabird watch was maintained by George (1992) and Moore (1993) during daylight hours from the bridge (ca. $7 \mathrm{~m}$ above sea level) of the $\mathrm{R} / \mathrm{V}$ Alpha Helix whenever sea conditions were $\leq$ Beaufort 06 and visibility was $\geq 1 \mathrm{~km}$. In addition, the ship's crew (one to three individuals) were keen observers and often made initial sightings. Sightings were made while underway at 14-18 $\mathrm{km} / \mathrm{h}(8-10 \mathrm{kn})$ and when the ship was stationary. Data recorded whenever marine mammals were seen included time (GMT), vessel position (using GPS), species, number and general behavior. Species was noted only when the whales were identified with certainty; none were identified by 'blow type.' Animals that could not be positively identified because of distance from the vessel or environmental conditions were listed as 'possible bowhead' or 'unidentified whale.'

In both 1992 and 1993, Russian scientists embarked in Provideniya, then the R/V Alpha Helix steamed to Bering Strait where oceanographic research began. Current meter moorings were recovered and deployed, and standard conductivity-temperature-density (CTD) profiles were taken at stations spanning the Chukchi Sea (see Weingartner, 1993). In 1993, a Biosonics echosounder (model 102) was towed intermittently during the cruise to sample the water column for plankton patches, via 200 and $420 \mathrm{kHz}$ sonar. The echosounder was towed from the port side of the Alpha Helix at roughly $2 \mathrm{~m}$ water depth.

\section{RESULTS}

A total of 166 hours of marine mammal/seabird watch were conducted from 16 September to 9 October 1992, and 172 hours from 16 September to 13 October 1993. Although the cruise track varied somewhat between years, each year it extended north and east from Bering Strait to waters near or north of Point Barrow, west across the northern Chukchi Sea roughly parallel to the ice edge, southeast along the Chukotka coast to Cape Vankarem, roughly east to Point Hope and back to Cape Serdtse-Kamen, before exiting the Chukchi Sea (Fig. 1). The ice edge, ca. $200 \mathrm{~km}$ (130 NM) farther north in 1993 than in 1992, defined the northern boundary of the area searched. The ship continued operations day and night, so substantial portions of the cruise track could not be surveyed because of darkness.

Although search conditions were generally very good (unlimited visibility, Beaufort sea scale 00-01) in 1992, and good ( $5 \mathrm{~km}$ visibility, Beaufort sea scale 01-03) in 1993, bowhead whales were not seen during the northward portion of the cruises paralleling the Alaskan coast, nor along the ice edge, in late September. Except for three sightings of six whales near the Bering Strait listed as 'possible bowheads' on 20-21 September, all bowheads seen in 1992 were about 37 $\mathrm{km}(20 \mathrm{NM})$ off the Chukotka coast, between Cape Schmidt and Cape Vankarem. On 1 October, 24 sightings totalling 76 bowhead whales were recorded during a search of roughly $112 \mathrm{~km}(60 \mathrm{NM})$ of cruise track between $68^{\circ} 40.0^{\prime} \mathrm{N}$, $177^{\circ} 18.5^{\prime} \mathrm{W}$ and $68^{\circ} 05.3^{\prime} \mathrm{N} 176^{\circ} 19.2^{\prime} \mathrm{W}$ (Fig. 1A).

Similarly, bowheads were seen only along the Chukotka coast in 1993. On 3 October, nine sightings totalling 50 bowhead whales were recorded during a search of roughly $167 \mathrm{~km}(90 \mathrm{NM})$ of cruise track between $68^{\circ} 48.0^{\prime} \mathrm{N}$, $178^{\circ} 21.9^{\prime} \mathrm{W}$ and $69^{\circ} 25.6^{\prime} \mathrm{N}, 179^{\circ} 18.5^{\prime} \mathrm{E}$ (Fig. 1B). Also seen during this search were gray whales ( 10 sightings totalling 49 whales) and 'unidentified whales' (7 sightings totalling 28 whales), all of which were likely either bowhead or gray whales. Bowhead and gray whales often were seen in close proximity $(\leq 100 \mathrm{~m})$ and this, combined with waning light, resulted in the relatively high number of whales that could not be positively identified. The only other bowheads seen during the 1993 cruise were two whales southwest of Wrangel Island on 4 October, one offshore Cape Schmidt on 5 October, and five seen (again among gray whales) near Cape SerdtseKamen on 8 October.

Bowheads near the Chukotka coast appeared to be feeding in the water column in both years; this was indicated by slow, non-directed movements and submergences without back rolls or a show of flukes. Physical features of the water column common to bowhead 'feeding areas' offshore Cape Schmidt included sharp salinity (proxy density) gradients at 

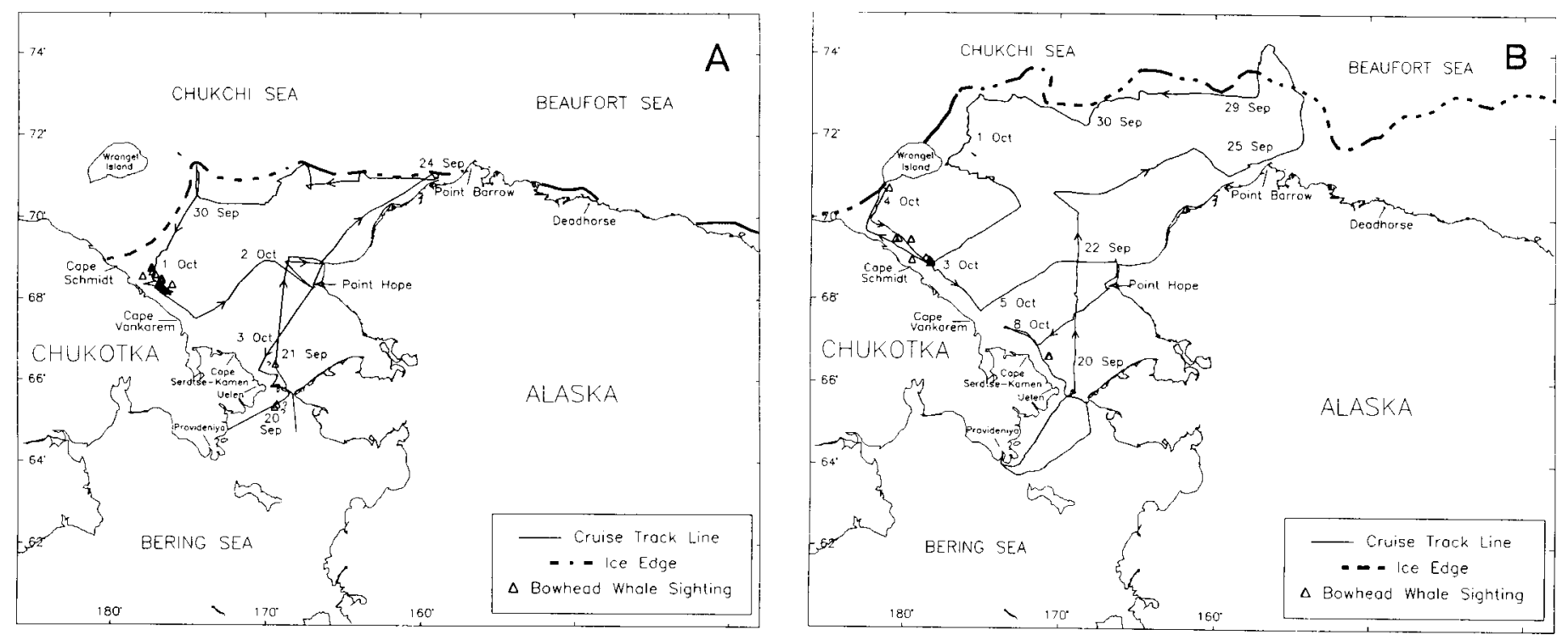

FIG. 1. Cruise track, approximate location of the ice edge and bowhead whale sighting locations during 1992 (A) and 1993 (B) Chukchi Sea cruises.

ca. $33-38 \mathrm{~m}$ depth in 1992, and at ca. $25-30 \mathrm{~m}$ depth in 1993 (Fig. 2). On 3 October 1993, the Biosonics was under tow as the ship, approaching Cape Schmidt, passed a group of 11 bowheads that appeared to be feeding. A distinct $5 \mathrm{~m} \times 8 \mathrm{~km}$ patch of zooplankton was detected at $25-30 \mathrm{~m}$ depth (i.e., at the depth of the salinity gradient) in water $35 \mathrm{~m}$ deep (Fig. 3). The euphausiid Thysanoessa rachii, a common bowhead prey species (Lowry, 1993), was the dominant zooplankter collected during a vertical tow of a $1 \mathrm{~m}$ diameter plankton collection net near the area of the patch. In addition, bowhead distribution on 3 October closely corresponded with a surface thermal boundary, identified by AVHRR. Together these data indicate that whales feeding near Cape Schmidt were strongly associated with salinity and thermal fronts, which may act to concentrate euphausiid prey.

In both years, the principal observers felt that many bowhead whales were likely missed during the high-count days. In 1992, George estimated that several hundred whales were within the $60 \mathrm{NM}$ strip of coast surveyed on 1 October. Similarly, in 1993, Moore estimated that at least 100-150 bowheads were likely offshore the portion of the Chukotka coast searched on 3 October. In 1993, bowheads milled slowly at the surface and dived inconspicuously, often without a detectable blow even when blowholes were clearly visible. In contrast, gray whales were relatively conspicuous as they swam steadily south parallel to the coast, spy-hopped, or rolled at the surface as the ship passed.

\section{DISCUSSION}

Bowhead whales were seen only along the Chukotka coast during opportunistic marine mammal/seabird search surveys in the Chukchi Sea in autumn 1992 and 1993. The confinement of bowhead whale sightings to the Chukotka coast is similar to findings from Chukchi Sea cetacean-sighting cruises conducted from Soviet whaling ships during October 1979 and September 1980 (Miller et al., 1986), and to incidental sightings made during surveys of Pacific walruses in September-October 1990 (Burns, 1993). Bowheads seen in 1992 and 1993 appeared to be feeding. In 1993, feeding whales were closely associated with a subsurface patch of zooplankton that coincided with salinity and temperature (proxy density) fronts. These observations generated several questions: When, from where and by what route do bowheads arrive along the Chukotka coast? Is the Chukotka coast an important feeding or staging area for the Bering Sea population? Can bowhead whale feeding areas be reliably identified by physical oceanographic features?

When bowheads arrive along the Chukotka coast, or whether whales occur there every year, is unknown (Burns, 1993). Some bowheads may summer offshore in the Chukchi Sea and move towards shore in August, as is the pattern in the Canadian Beaufort Sea (Moore and Reeves, 1993). This strategy has been suggested by Russian biologists (Bogoslovskaya et al., 1982; Bessonov et al., 1990), largely on the basis of reports of whales near the coast by villagers at Uelen, Inchoun and Cape Vankarem. Since 1992, the North Slope Borough has sponsored a joint program with Native hunters of Chukotka to count bowheads along the Chukotka coast in summer and autumn. Preliminary findings indicate that Native hunters see bowhead whales in the waters north of Chukotka from June through August (T. Albert, pers. comm. 1994). However, available data remain insufficient to determine if bowheads summer in waters north of Chukotka (Burns, 1993). There have been no broadscale aerial surveys of the Chukchi Sea west of the International Date Line and the few ship surveys have been, by necessity, limited in their scientific objectives (Dahlheim et al., 1980; Miller et al., 1986).

Bowheads seen along the Chukotka coast may swim there from summering areas in the eastern Beaufort Sea. Whales could cover the ca. $1800 \mathrm{~km}$ distance in about 15 days, if they 


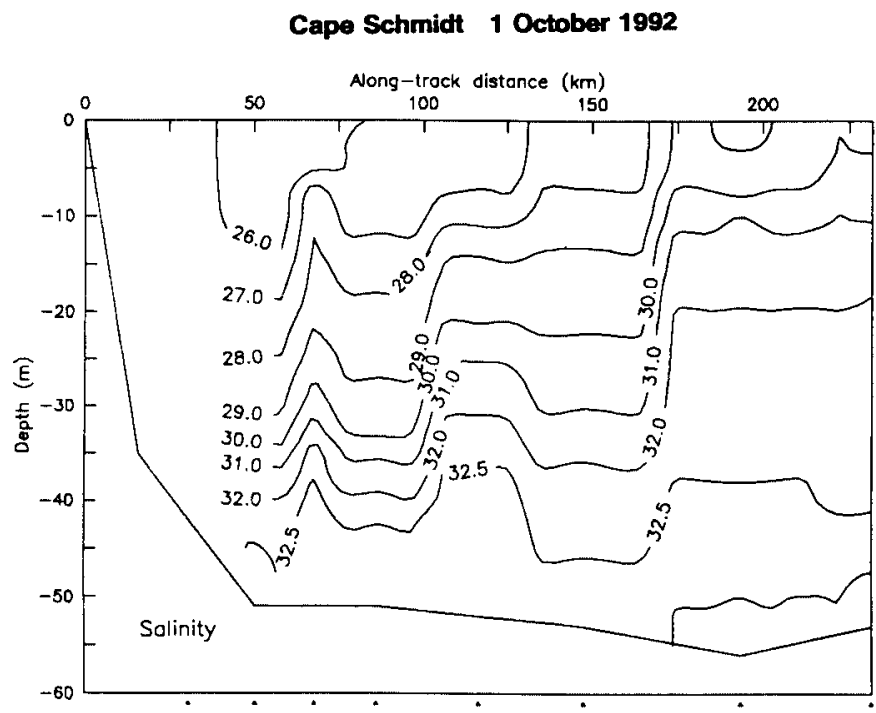

Cape Schmidt 3 October 1993

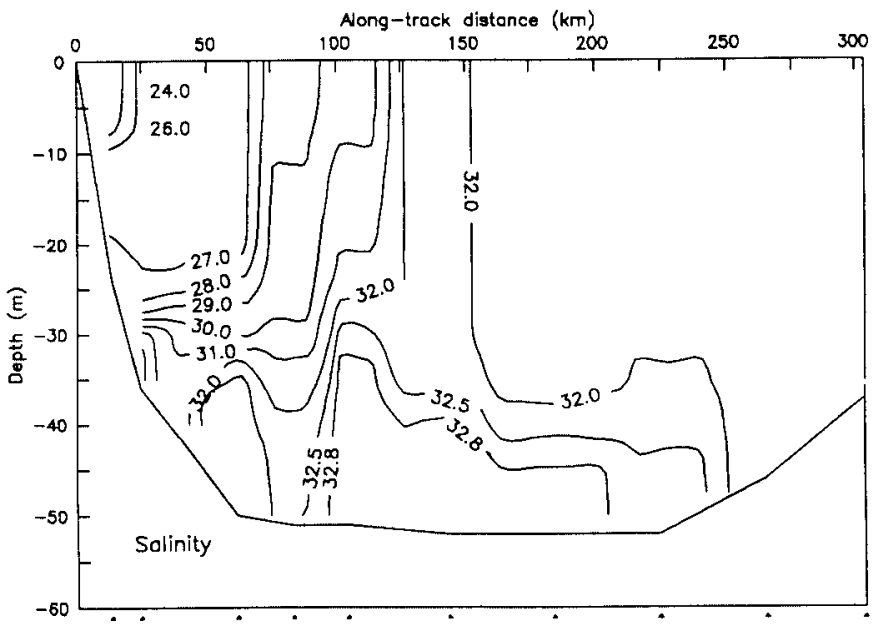

FIG. 2. Salinity contours offshore Cape Schmidt on 1 October 1992 and 3 October 1993. Along-track distance is measured in $\mathrm{km}$ from shore; $0=$ shoreline.

swam continuously at $5 \mathrm{~km} / \mathrm{h}$, the low-average swimming rate reported for the autumn migration (Würsig and Clark, 1993). Assuming that whales stop to rest, feed, or deviate around ice during migration, as has been observed (Wartzok et al., 1990) and indicated from tagging studies (Mate and Krutzikowsky, 1993), three weeks seems a reasonable minimum estimate for migration from the eastern Beaufort Sea to the Chukotka coast. Bowheads swimming west from the eastern Beaufort Sea in early August, as observed in 1982-86 (Moore et al., 1989), could easily arrive along the Chukotka coast by September. Moreover, the 'possible bowheads' seen near Bering Strait on 20-21 September 1992 (see '?' Fig. 1A), and the subsequent report of four bowheads seen at virtually the same locations on 22 September 1994 (Johnson, 1994) suggests that some whales may reach the northern Bering Sea by late September.

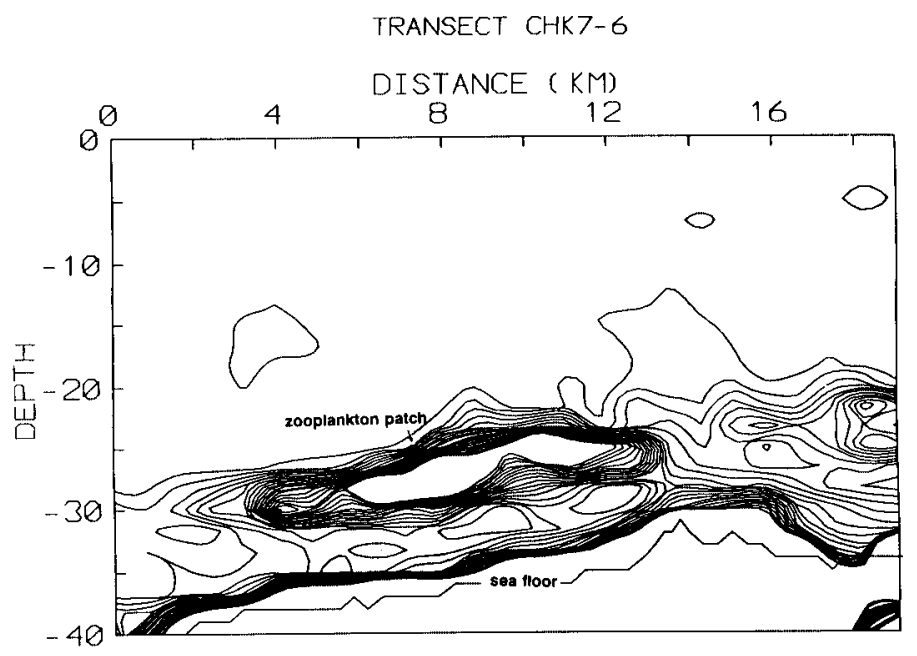

FIG. 3. Patch of zooplankton identified via Biosonics tow through waters where bowhead whales appeared to be feeding near Cape Schmidt on 3 October 1993. Along-track distance is measured in $\mathrm{km}$ from shore; $0=$ shoreline.

Bowheads were observed swimming west in the eastern Alaskan Beaufort Sea on 31 August 1992 and 1 September 1993, although peak sighting rates did not occur until 19 October 1992 and 29 September 1993 (Treacy, 1993, 1994). So, bowheads seen in early October along the Chukotka coast during the Chukchi Sea cruises could have migrated there from the eastern Beaufort Sea. However, if bowheads do cross the Chukchi Sea in late August and September, their route remains largely unknown. The few recent records of bowheads in the central Chukchi Sea include two whales at ca. $72^{\circ} \mathrm{N}, 169^{\circ} 30^{\prime} \mathrm{W}$ reported during surveys for walruses conducted by the U.S. Fish and Wildlife Service in late September 1985 (Moore and Clarke, 1992), and five bowheads at ca. $71^{\circ} \mathrm{N}, 170^{\circ} 40^{\prime} \mathrm{W}$ seen during the 1994 Chukchi Sea cruise on 29 September (Johnson, 1994). Sightings from broadscale aerial surveys conducted in late September and October from 1982 to 1991 were confined to the northeast Chukchi Sea (Moore and Clarke, 1992) and no bowheads were seen in the northern or mid-Chukchi Sea during the 1992 and 1993 cruises, despite good viewing conditions.

Analysis of the $\delta^{13} \mathrm{C}$ levels in bowhead whale tissues precipitated a challenge to the prevailing opinion that the eastern Beaufort Sea is the primary feeding area for the Bering Sea bowhead population (Schell et al., 1989). The $\delta^{13} \mathrm{C}$ signal detected in baleen, fat and muscle tissues of bowhead whales killed by Alaskan Eskimo hunters is similar to that of zooplankton in the Chukchi and northern Bering Sea, rather than the $\delta^{13} \mathrm{C}$-poor waters of the eastern Beaufort Sea. This leads Schell and Saupe (1993) to conclude that bowheads do much of their feeding in the western and southern parts of their range. Conversely, Lowry (1993) argues that most feeding is done in the eastern Beaufort Sea, basing his conclusion largely on direct behavioral observations summarized in Würsig et al. (1989).

The intermittent reports of large aggregations of bowhead whales along the coast of Chukotka over the last 15 years suggest that these waters may be an important feeding or 
staging area during autumn migration. Bowheads, like other baleen whales, must find relatively high-density prey patches to feed efficiently (Lowry, 1993). We provide here the first report of a zooplankton aggregation, measuring $5 \mathrm{~m} \times 8 \mathrm{~km}$, at a site where bowheads appeared to be feeding along the Chukotka coast. This patch is larger than that reported for a surface layer of copepods (Calanus finmarchicus), measuring $2500 \mathrm{~km}^{2}$, reported in a northern right whale (Eubalaena glacialis) feeding area (Wishner et al., 1988); and for a subsurface swarm of Antarctic krill (Euphausia superba), measuring ca. $700 \mathrm{~m} \times 35 \mathrm{~m}$, at which a southern right whale (E. australis) stopped swimming and began feeding (Hamner et al., 1988). T. rachii, the principal zooplankter collected near the patch off Chukotka in 1993, was previously found to be the dominant prey species in the stomachs of 10 of 18 bowheads landed at Barrow, and of 3 of 12 whales taken at Kaktovik, Alaska (Lowry, 1993) indicating that this euphausiid is an important prey species for bowheads across their autumn range.

The association of bowheads offshore Chukotka with subsurface density and surface thermal fronts is similar to findings from a two-year study of bowhead distribution, zooplankton abundance and oceanographic regimes in the southern Beaufort Sea (Bradstreet et al., 1987). In brief, feeding whales offshore Canada seemed associated with dense subsurface layers of zooplankton at convergence zones between Arctic Ocean and Mackenzie River plume waters. When the distribution of plume waters, mapped from satellite imagery, was compared to whale distribution, results suggested that whales occurred near or just beyond the plume edge.

Gauging the importance of the Chukotka coast as a bowhead staging or feeding area will require a coordinated research program to investigate physical oceanographic features, primary and secondary productivity, forage quality and quantity, and whale residence times. The Siberian Coastal Current flows southeastward along the Chukotka coast and is characterized by high salinities and nutrient levels, likely of Bering Shelf origin (Coachman and Shigaev, 1992). The influence of this current in local production or advection of bowhead prey along the Chukotka coast remains unknown. A key life history question is how important, calorically, this feeding area is to the Bering Sea bowhead population. Addressing these topics would fill some important gaps in our understanding of the role of these whales in the arctic ecosystem.

\section{ACKNOWLEDGEMENTS}

The field portion of this work was completed on the NSF-funded (NSF-OPP-9218756) Japanese-Russian-American Chukchi Sea Circulation Study Cruises during 1992 and 1993. We thank John Smithisler (Institute of Marine Science, University of Alaska Fairbanks) for assistance in identifying whales, Captain Thomas Callahan, First Mate Bill Rook, the crew of the R/V Alpha Helix and our Russian and Japanese colleagues for their perseverance and assistance during the shipboard watches. Michele Johnson (Science Applications International Corporation [SAIC]) produced the cruise track maps. Dave Checkley (Scripps Institution of Oceanography), Janet Clarke (SAIC), Dave Withrow (U.S. National Marine Mammal Laboratory), and two anonymous reviewers provided constructive comments on the draft manuscript. Our thanks to all.

\section{REFERENCES}

BESSONOV, B., MELNIKOV, V.V., and BOBKOV, V.A. 1990. Distribution and migration of cetaceans in the Soviet Chukchi Sea. Minerals Management Service, Alaska Outer Continental Shelf Region, Third Information Transfer Meeting. OCS Study MMS 90-0041:21-26.

BOGOSLOVSKAYA, L.S., VOTROGOV, L.M., and KRUPNIK, I.I. 1982. The bowhead whale off Chukotka: Migrations and aboriginal whaling. Report of the International Whaling Commission 32:391-399.

BRADSTREET, M.S.W., THOMSON, D.H., and FISSEL, D.B. 1987. Zooplankton and bowhead whale feeding in the Canadian Beaufort Sea, 1986. Unpubl. ms. Available in Bowhead Whale Food Availability Characteristics in the Southern Beaufort Sea: 1985 and 1986, Environmental Studies No. 50, from Canadian Department of Indian Affairs and Northern Development, Ottawa, Ontario K1A OH4, Canada.

BURNS, J.J. 1993. Epilogue. In: Burns, J.J., Montague, J.J., and Cowles, C.J., eds. The bowhead whale. Special Publication Number 2, The Society for Marine Mammalogy. Lawrence, Kansas: Allen Press, Inc. 745-764.

COACHMAN, L.K., and SHIGAEV, V.V. 1992. Northern BeringChukchi Sea ecosystem: The physical basis. In: Nagel, P.A., ed. Results of the Third Joint US-USSR Bering \& Chukchi Seas Expedition (BERPAC), Summer 1988. Washington, D.C.: U.S. Fish and Wildlife Service.17-27.

DAHLHEIM, M., BRAY, T., and BRAHAM, H. 1980. Vessel survey for bowhead whales in the Bering and Chukchi Seas, June-July 1978. Marine Fisheries Review 42(9-10):51-57.

HAMNER, W.M., STONE, G.S., and OBST, B.S. 1988. Behavior of southern right whales, Eubalaena australis, feeding on the Antarctic krill, Euphausia superba. Fishery Bulletin 86(1): $143-150$.

JOHNSON, M.M. 1994. 1994 Japanese/Russian/American Chukchi Sea Circulation Study: Marine Mammal and Seabird Observations. Unpubl. ms. Available at the Institute of Marine Science, University of Alaska, Fairbanks, Alaska 99775, U.S.A.

LOWRY, L.F. 1993. Foods and feeding. In: Burns, J.J., Montague, J.J., and Cowles, C.J., eds. The bowhead whale. Special Publication Number 2, The Society for Marine Mammalogy. Lawrence, Kansas: Allen Press, Inc. 201-238.

MATE, B.R., and KRUTZIKOWSKY, G. 1993. Movements and dive habits of bowhead whales from satellite-monitored radio tags. Minerals Management Service, Alaska Outer Continental Shelf Region, Fifth Information Transfer Meeting. OCS Study MMS 93-0043:101-102.

MILLER, R.V., RUGH, D.J., and JOHNSON, J.H. 1986. The distribution of bowhead whales, Balaena mysticetus, in the Chukchi Sea. Marine Mammal Science 2:214-222. 
MOORE, S.E. 1992. Summer records of bowhead whales in the northeastern Chukchi Sea. Arctic 45(4):398-400.

MOORE, S.E., and CLARKE, J.T. 1992. Distribution, abundance and behavior of endangered whales in the Alaskan Chukchi and western Beaufort Seas, 1991: With a review 1982-91. OCS Study MMS 92-0019, Final Report prepared for the U.S. Minerals Management Service, Alaska Outer Continental Shelf Region. Prepared by SAIC, Maritime Services Division. 237 p.

MOORE, S.E., and REEVES, R.R. 1993. Distribution and movement. In: Burns, J.J., Montague, J.J., and Cowles, C.J., eds. The bowhead whale. Special Publication Number 2, The Society for Marine Mammalogy. Lawrence, Kansas: Allen Press, Inc. 313-386.

MOORE, S.E., CLARKE, J.T., and LJUNGBLAD, D.K. 1989. Bowhead whale (Balaena mysticetus) spatial and temporal distribution in the central Beaufort Sea during late summer and early fall 1979-86. Report of the International Whaling Commission 39:283-290.

SCHELL, D.M., and SAUPE, S.M. 1993. Feeding and growth as indicated by stable isotopes. In: Burns, J.J., Montague, J.J., and Cowles, C.J., eds. The bowhead whale. Special Publication Number 2, The Society for Marine Mammalogy. Lawrence, Kansas: Allen Press, Inc. 491-509.

SCHELL, D.M., SAUPE, S.M., and HAUBENSTOCK, N. 1989. Bowhead whales (Balaena mysticetus) growth and feeding as estimated by $\delta^{13} \mathrm{C}$ techniques. Marine Biology 103:433-443.

TREACY, S.D. 1993. Aerial surveys of endangered whales in the Beaufort Sea, Fall 1992. OCS Study MMS 93-0023. 74 p. + appendices.

-1994. Aerial surveys of endangered whales in the Beaufort Sea, Fall 1993. OCS Study MMS 94-0032. 78 p. + appendices.
WARTZOK, D., WATKINS, W.A., WÜRSIG, B., GUERRO, J., and SCHOENHERR, J. 1990. Movements and behaviors of bowhead whales. Final Report submitted to Amoco Production Company. Available from D. Wartzok, Dean of Graduate School, University of Missouri, St. Louis, Missouri 631214499, U.S.A. 197 p.

WEINGARTNER, T.J. 1993. The physical oceanography of the northeast Chukchi Sea. Minerals Management Service, Alaska Outer Continental Shelf Region, Fifth Information Transfer Meeting. OCS Study MMS 93-0043:263-270.

WISHNER, K., DURBIN, E., DURBIN, A., MACAULAY, M., WINN, H., and KENNEY, R. 1988. Copepod patches and right whales in the Great South Channel off New England. Bulletin of Marine Science 43(3):825-844.

WÜRSIG, B., and CLARK, C. 1993. Behavior. In: Burns, J.J., Montague, J.J., and Cowles, C.J., eds. The bowhead whale. Special Publication Number 2, The Society for Marine Mammalogy. Lawrence, Kansas: Allen Press, Inc. 157-199.

WÜRSIG, B., DORSEY,E.M., RICHARDSON, W.J., and WELLS, R.S. 1989. Feeding, aerial and play behaviour of the bowhead whale, Balaena mysticetus, summering in the Beaufort Sea. Aquatic Mammals 15(1):27-37.

ZEH, J.E., CLARK, C.W., GEORGE, J.C., WITHROW, D. CARROLL, G.M., and KOSKI, W.R. 1993. Current population size and dynamics. In: Burns, J.J., Montague, J.J., and Cowles, C.J., eds. The bowhead whale. Special Publication Number 2, The Society for Marine Mammalogy. Lawrence Kansas: Allen Press, Inc. 409-489.

ZEH, J.E., GEORGE, J.C., and SUYDAM, R. 1995. Population size and rate of increase, 1978-1993, of bowhead whales, Balaena mysticetus. Report of the International Whaling Commission 45:339-344. 